Article

\title{
Technology, Gender, and Climate Change: A Feminist Examination of Climate Technologies
}

\author{
Tina Sikka \\ Department of Media, Culture and Heritage, School of Arts and Cultures, Newcastle University, \\ Newcastle NE1 7RU, UK; tina.sikka@newcastle.ac.uk
}

Received: 17 August 2018; Accepted: 30 October 2018; Published: 2 November 2018

check for updates

\begin{abstract}
In this article, I examine the subject of justice as it relates to gender and climate change by focusing on two specific strategies, namely, the geoengineering strategy of ocean fertilization, and renewable energy as a means of mitigation (where mitigation is understood as the adoption of technologies and practices that aim to slow the rise of greenhouse gas emissions). My overarching argument is that iron fertilization geoengineering is not consistent with the feminist values of justice embedded in feminist standpoint theory and feminist contextual empiricism. Alternative mitigation strategies, on the other hand, go much further in meeting these objectives and virtues.
\end{abstract}

Keywords: feminism; climate change; gender; geoengineering; environment; standpoint

In this article, I conduct a comparative analysis, using feminist science studies as a framework to examine the future of climate change mitigation. Currently, there is disagreement within the scientific and policy communities with respect to how to confront climate change in a manner that addresses questions of justice and equity. In this piece, I examine the subject of justice as it relates to gender and climate change by contrasting two specific strategies, namely, the geoengineering strategy of ocean fertilization as well as renewable energy as a means of mitigation (where mitigation is understood as the adoption of technologies and practices that aim to slow the rise of greenhouse gas emissions). To this end, I concentrate specifically on renewable energy initiatives that include wind and solar.

I draw on feminist science studies, particularly feminist standpoint theory (FST), to develop a feminist contextual empiricist (FCE) approach to scientific knowledge with which to examine these two competing strategies. Employing FST allows for the ability to, one, unpack the materially grounded and gendered values, truth claims, and assumptions that shape the scientific, media and policy discourse around ocean fertilization geoengineering and renewable energy technologies; two, assess whether the values, truth claims, methodologies and questions relied upon are consistent with the virtues of feminist science; and three, question whether, and if so how, the conclusions reached by these analyses fulfill larger objectives of social justice and equity.

The prospect of deploying radical technologies to combat climate change, rather than undergoing difficult structural socio-economic and cultural change, is seductive to say the least. Over the past few decades, a compendium of these technologies have come to be known as geoengineering. As a category, geoengineering refers to technologies whose goal is to mitigate climate change either through the direct removal of carbon dioxide from the atmosphere, or by reflecting heat-absorbing radiation back into space. These techniques vary considerably from ones that present almost as science fiction, e.g., oscillating reflectors in space, to the more plausible biochar or carbon capture and storage. The most recent 2018 report by the Intergovernmental Panel on Climate Change (IPCC) mentions geoengineering as a possible last resort, if "mitigation efforts do not keep global mean temperatures below 1.5 degrees Celsius", with a preference for carbon dioxide removal (CDR) technologies over solar radiation management (SRM) in light of potential side effects, knowledge gaps, and potential for moral hazard [1]. Because the report treats CDR technologies as more in line with traditional 
mitigation strategies, it focuses on the most modeled and researched SRM approach, stratospheric aerosol injection, as the most likely option indicating the significance of geoengineering technologies in the climate debate going forward. What is interesting about the IPCC's most recent report, with respect to gender, is that it specifically discusses issues of gender inequality and the importance of climate research that is "gender informed". It is also the case that the panel itself has worked to recruit more women, albeit from a very low level, encourage their expertise, and transform the working environment. However, with respect to scientific practice, because the panel's work involves a large meta-analysis of existing climate science, it is largely the case that the specific principles of feminist research, as articulated by Longino, are not adequately reflected in the science itself. This would require a comprehensive restructuring of climate science to incorporate heterogeneous approaches, local interests and needs, and highlight the gender differentiated causes and effects of climate change.

With respect to nomenclature, throughout this article the terms iron fertilization, ocean fertilization, and iron seeding are used interchangeably. Geoengineering is used to encapsulate and refer to the several techniques including, but not limited to, iron fertilization. The decision to use iron fertilization as the primary case study rests on a variety of factors - the most significant of which is its prominence among the various geoengineering techniques available. Despite the moratorium on testing under the London Protocol of the Convention on Biological Diversity (see below), small-scale, research-oriented testing and experimentation is still permitted and continues apace. ${ }^{1}$ In addition to the 2008 Haida G'waii experiment, several other experiments, from the 2009 LOHAFEX joint Indian and German experiments, cleared by the German Government, to the similarly sanctioned 2004 EIFEX, a European trial, iron fertilization has considerable institutional, political, and corporate support [2-4]. The most recent iron fertilization project of note is one scheduled to take place in 2018 off the coast of Coquimbo, Chile. Oceanos Marine Research Foundation, headquartered in Vancouver, Canada, is currently seeking permits for the trial from the Chilean Government [5].

Helen Longino's feminist and contextual approach to science has been chosen as the primary framework for examining and comparing iron fertilization to mitigation for several reasons. These include its thematization of social rather than individualized knowledge; its endorsement of publicly accessible rational inquiry; its incorporation of values and background assumptions as essential parts of scientific research; and its normative conception of knowledge [6-10]. Longino's FCE also refrains from essentializing feminist ways of knowing while retaining the ability to critique conventional scientific research-particularly with respect to gender relations.

It is also important to flesh out the ways in which Longino's local epistemology is feminist. Specifically, I argue that feminism manifests itself not in the belief there are particular ways of knowing accessible only to women, but that the scientific virtues of empirical adequacy, novelty, ontological heterogeneity, complexity/mutuality of interactions, applicability to human needs, and decentralization/universalization of power promote the feminist goal of revealing the operation of gender: "If the context is gendered (in the sense of being structured by gendered power asymmetries), inquiry guided by these virtues is more likely to reveal it or less likely to preserve its invisibility than the traditional virtues" [11].

Moreover, Longino contends that doing science as a feminist, in conversation with other feminists, involves interventions that are inclusive, local, contextual, interested, non-productionist and interactionist. Feminism, understood in this way,

... is at its core in part about the expression of human potentiality. When feminists talk of breaking out and do break out of socially prescribed sex roles, when feminists criticize the institutions of dominations, we are thereby insisting on the capacity of humans -male and female -to act on perceptions of self and society and to act to bring about changes in self and society on the basis of these perceptions. [12]

1 The Convention also does contain enforcement mechanisms. 
Thus, this approach, also feminist, is so the sense that it is dedicated to "the expansion of human potentiality" [12] in line with a politically committed scientific program.

FST is both a method of critique and epistemology that also aims to defend feminist knowledge as both coherent and intrinsically valuable. FST centers women's experiences and ways of knowing explicitly. Its objective with respect to science, according to [13], is to remove oppressive power relations and work towards a scientific practice that makes women's experiences the point of departure [14]. As such, it can be distinguished from FCE, which retains a specific kind of faithfulness to empiricism. A more fulsome discussion of FST is effected below.

Turning back to the subject at hand, my overarching thesis is that iron fertilization geoengineering is not consistent with the feminist values of justice embedded in FST or FCE. Mitigation strategies employing solar and wind, on the other hand, go much further in meeting these objectives and virtues. This approach provides a novel argument in support of pursuing renewable energy mitigation strategies, such as wind and solar, in place of geoengineering. I begin with an overview of wind and solar strategies followed by an explanation of iron fertilization geoengineering. I then critique the traditional ways in which gender is incorporated into discussions around climate change and the environment. Next, I provide an overview of FST and FCE with respect to what each contributes to the subjects of climate change and gender. I focus specifically on two of Helen Longino's feminist virtues, namely empirical adequacy, and applicability to current human needs, which I then use to assess iron fertilization and wind and solar energy alternatives. I question whether either is sufficiently attendant to gender and if they can be said to reflect principles of justice. The two virtues of empirical adequacy and relevance to human needs have been chosen because of their thematization in contemporary geoengineering discourse. Scientific bodies, lobby groups, the media, and governments, to justify further research and potential testing of geoengineering, consistently draw upon claims to scientific truth, justification, empirical evidence, as well as to humanitarian necessity and socio-ecological responsibility.

Methodologically, this is article is engaged in a close discursive reading of widely cited and reputable scientific texts aimed at the study of scientific practice. This involves an evaluation of scientific knowledge claims in terms of how they are produced, the process by which they are accepted and/or rejected, and how scientific controversies are resolved $[15,16]$. This kind of sociological accounting of scientific knowledge claims also includes the study of how claims emerge, how they are framed, and what values they reflect-which is consistent with discourse analysis as well as feminist science studies. With respect to geographical specificity, this analysis relies on studies that take a global perspective (global average temperatures etc.), which is one of the criticisms a feminist approach highlights-i.e., the lack of regional and local specificity which, in this case, applies to studies of geoengineering specifically. Critically examining geoengineering as a set of knowledge claims that constitute a form of political activity that is generalized and assessed through a feminist lens is constitutive of the research method employed in this article [17-20].

The thesis that climate science, and science in general, would benefit from feminism is not, for the purposes of this paper, dispositional. Rather, as I argue below, it rests on the belief that the modes of analysis that have historically developed out of feminism, as it relates to its critique of institutions of domination, gender roles and behavior (misogyny, androcentrism), and socio-economic relations, also lend themselves to scientific practicel. For instance, inserting feminist insights into scientific practice in ways that uncover and critique the traditional values of individuality, distance, and abstraction can help to refocus attention to the public good, power relations, and ethics as primary principles of science [21-24]. Both FCE and FST hold this to be true.

As such, using a feminist approach allows social scientists to "see inside the process of science" in ways that

... help scientists to explain the social conditions in both scientific institutions and the surrounding society that tend to encourage empirically more adequate beliefs; identify background assumptions that tend to distort the results of research; conceptualize and 
design research in ways that avoid powerful cultural biases; [and] interpret and select data to produce the most reliable evidence for and against hypotheses ... [25]

This, coupled with an approach that sees the production of knowledge as the outcome of social processes within communities rather than by individuals, reflects sound, feminist scientific practice.

\section{Mitigation and Renewable Energy}

Mitigation refers to strategies aimed at removing existing greenhouse gas emissions from the atmosphere and/or slowing the rate of emissions. It is distinct from adaptation, which is typically understood as a set of policies that are designed to enhance environmental resilience and reduce general vulnerability to the impacts of climate change. Renewable approaches to energy production, for the purposes of this paper, refers to mitigation strategies that include increased energy efficiency in terms of distribution and supply, the production of fuel-efficient vehicles and electric appliances, and the growth in renewable energy sources such as solar, wind, and hydro [26-28].

The idea of renewable energy sources as practicable on a large scale is grounded in studies that prove their viability in the form of lower costs, improved technological capabilities, and overall better planning. Novel combinations of these technologies, such as modern wind turbines coupled with photovoltaic systems, can provide systems that ensure both the " ... balance and security of the bulk power system" $[29,30]$. The most recent study of renewable energy put out by the International Energy Agency (IEA) suggest that these sources have contributed to considerable energy savings among member countries (1337 million tons of oil-equivalent in 2011), new business opportunities, better vehicle efficiencies, and marked improvements in residential technologies (light, heating, etc.) [31]. The decreasing cost of solar power, now at 50 cents per watt, cheaper wind power, more investment in renewables (e.g., Germany), and decreasing use of coal in countries like China gives reason for some optimism that climate mitigation targets (1.5-2 degrees Celsius warming) can be reached through the development of a whole package of energy alternatives that include, at the forefront, wind and solar. However, it is also the case that considerably more investment and changes in consumption patterns and energy use are needed to keep within the 1.5-2 degrees Celsius temperature limit. This would require a 55 per-cent emission cut by 2050 according to the IEA, and, as is widely acknowledge, the international community is nowhere close to committing to this.

\section{Iron Fertilization}

Iron fertilization, on the other hand, is a CDR geoengineering technique whose objective is to capture and sequester carbon dioxide [32-34]. This approach aims to remove $\mathrm{CO}_{2}$ from the atmosphere by adding iron to the surface of the ocean, which would stimulate the production of carbon dioxide absorbing phytoplankton. The phytoplankton would then sink to the ocean floor having removed carbon dioxide directly from the atmosphere. There have been several studies of this approach and several small-scale trials, including one off Haida G'waii in 2012 and a 2003 Southern Ocean Iron Experiment, whose purpose was to gather data on its efficacy, costs, and potential side effects [35,36] (see below). Currently, there is disagreement among scientists concerning the long-term effectiveness of iron fertilization as well as significant apprehension about potential side effects [37,38].

Ocean fertilization in particular makes for a salient case study because of its history, recent testing, and extensive media coverage. The earliest tests, beginning in the 1980 and 90s, were directed at establishing a link between algae growth and iron levels rather than climate dynamics. In the early 2000s, scientists began to focus on questions related to algae growth and climate change specifically. Russ George and Michael Markels are two important actors who set up companies such as Carboncorp USA, GreenSea Ventures, and Planktos Inc. which tested, often without permission, the ability to "stimulate plankton blooms, sequester carbon and sell the carbon offset credits" [39]. Russ George's 2012 unsanctioned test in Canada's Pacific Northwest is especially notable-particularly in light of the media coverage it received at the time [40]. In light of the possibility of more rogue tests like 
these, ocean fertilization, as a means of climate change mitigation, was addressed at meeting of the Convention of Biodiversity during which the parties placed a moratorium on its use (albeit not on research) in 2008.

Significant recent university and government interest in this technique serves as another reason why iron fertilization was chosen as the case study. This includes research like the LOHFEX test (LOHA is Hindi for iron, FEX stands for Fertilization Experiment), conducted in 2009 by the Indian and German governments, and intensive modeling done by scientists at the Universities of Hawaii, Southern California, and Amsterdam. Also significant is the argument that iron fertilization's relative inexpensiveness and ability to address the problem of climate change at its source by removing carbon from the atmosphere, makes it more likely to be used than costlier SRM projects that merely offset emissions. It is important, however, to acknowledge that much of the contemporary support for iron fertilization frame it as a complement to, rather than a replacement of, traditional mitigation strategies. How this balance is to be achieved however, as well as who defines this balance and according to what parameters, remains to be seen.

\section{Gender and Climate Change}

By and large, it is generally accepted that the place of gender in climate change discourse constitutes a critical dimension of contemporary climate analysis and warrants more attention. Gender mainstreaming constituted an increasingly popular way in which to incorporate innovative feminist principles into science and policy. Over the past five years the European Union taking a lead internationally in incorporated gender as a form of policy practice as part of their "strategic engagement for gender equality" program. With respect to scientific practice and labor, the Commission now compiles reports, e.g., their Horizon 2020 report titled "Closing Gender", that details the gendered inequalities reflected in science education, labor statistics, decision-making processes, and rates of attrition [41]. The Commission now requires, with respect to scientific practice, that all scientific reports include impact assessments that account for gender, the collection of sex-disaggregated data, gender equal implementation targets (including quotas), and impact assessments that reflect gender-specific concerns $[24,42]$. While this approach is laudable and has seen some increases in, for example, the presence of women in science faculties of PhD. conferring institutions in the EU, as well as on the boards of companies, I argue it does not adequately tackle the subject of gender inequality with respect to epistemology that feminist contextual empiricism does by dealing with the practice of science itself [39]. Moreover, gender mainstreaming has also been criticized for being too vague and uneven a concept such that, in its current form, it has tended to replace a more critical feminist analysis for one that is more politically neutral while also facilitating neoliberal development regimes [43,44]. Expanding the remit of the EC to go beyond gender equality in research and innovation to examining how science is done would go a long way to getting to the root of inequality in science by going one step beyond gender mainstreaming.

On the level of impact, the study of how women are impacted by climate-related disasters in such places as Haiti, Thailand, Indonesia and even New Orleans is of particular importance. For example, studies of aftermath of the 2010 Pakistani floods by Oxfam have revealed that not only were a majority of the victims women, but also that women in particular found it difficult to recover as they "were either overlooked in the distribution of relief or were unable to reach places of relief distribution due to social norms that restricted their mobility" $[45,46]$. This kind of research is particularly significant as it aims to empirically ground the impacts climate change has on marginalized social groups [47-50]. Sherilyn MacGregor has done similar work in the area of political theory by demonstrating how notions of environmental citizenship and other seemingly egalitarian political ideals and projects prevent a more granular discussion of social conditions, rights, and nonhierarchical relations consistent with feminist epistemology [51]. She approaches climate change as a deeply gendered phenomenon by using feminist constructivist analysis to examine the climate debate in light of power relations and hegemonic masculinity in ways that push the discussion out of simple gender mainstreaming 
and modernization and towards one that encompasses many of the epistemic principles laid out by Longino [52].

I argue that in order for gender equity and social justice to become a constitutive part of climate mitigation, a more complete understanding of the dynamic of gender and climate change is needed. FST and FCE provide a critical contribution to this area of research.

\section{Gender, Mitigation and Geoengineering}

Although FCE and FST and hold qualitatively different approaches to feminism-particularly with respect to their treatment of feminist ways of knowing and epistemic privilege, their valuation of empirical knowledge, and their contrasting stands on objectivity and diversity-they have been placed alongside one another in this article for several reasons. Most notably is the fact that both FCE and FST posit stances that incorporates political and social values into the process of knowledge production.

Recent work done by Kristen Intemann and Sharon Crasnow [53,54] further illustrate how contemporary FCE and FST have begun to converge into what Intemann calls "standpoint empiricism". They discuss how both approaches value wide participation, diverse scientific community involvement, ethico-political commitments, and the critical challenging of default assumptions. Both FST and FCE are also social, contextualist, and normative in taking "communities ... to be the locus of justification ... recognizing] that justification takes place within a particular context ... and rejecting the view of objectivity as "value-free" [53].

Overall, the two central pillars of the modality of FST I rely on for this analysis are that, "knowledge is situated and perspectival, and that there are multiple standpoints from which knowledge is produced" [55]. The most significant contribution of FST is its assumption that marginalized communities of women, who are further stratified along the lines of race, sexuality, and class, are shaped by unequal power relations, and thus have access to a fundamentally unique understanding of the world. It is this view or standpoint, I contend, that must be used and expanded upon in order unpack the values and assumptions that underlie both geoengineering and solar and wind energy alternatives as well as the possibility of distributed and community-controlled energy.

As such, feminist standpoint theory, because it is centered in the experience of marginalization, provides a vision of power relations and political consciousness that, when strived for, can contribute to, and enrich our understanding of climate change and its proposed solutions. Feminist authors drawing on FST have criticized many of the assumptions that underlie predictive science for ignoring the "social factors underpinning scientific practice" [56]), and for focusing on subjects and issues that have "clearly been skewed towards men's perception of what they find puzzling" [22].

Climate research in general requires a greater incorporation of feminist insights. Current research practices used to produce evidence of the safety, efficacy and cost-effectiveness of geoengineering tend to rely on predictive assumptions that emphasize the "characteristics of distance, individuality, autonomy, and abstraction" while overlooking the values of context, multiplicity, complexity, and complication emphasized in feminist science [57]. Feminist scientific values aim to situate climate science within a larger context and examine climate change as a phenomenon "inextricably wrapped up in social relations of power and oppression" while also putting forth solutions that not only "promote social justice in responses to climate change", but also to act "ethically and in solidarity with those suffering from the effects of climate change" [58,59]. With regards to solar and wind technologies, most of the analysis from government bodies, NGOs and think tanks rely on the former type of scientific practice with particular attention paid to the calculation of precisely how much they contribute to stabilizing emissions, the amount of short-term (or long-term) GDP reduction that could be experienced, as well as micro versus macroeconomic costs (of the technology and on the economy) which, while important, leaves out consideration of the larger social and political context within which science is being done.

A notable example of this can be found in one of the most widely cited and authoritative reports produced by the IPCC which provides a technical summary on climate change mitigation research. 
The report, titled, "Renewable Energy Sources and Climate Change Mitigation", draws heavily on large-scale integrated modeling in its assessment of various renewable energy sources including solar, wind, geothermal, hydro and bioenergy. Its assessment of ocean energy, for example, focuses on resource potential, research and development, global markets, costs and concludes that, in the future,

... scenarios modelling [sic] process will need to increasingly incorporate the range of potential ocean energy technology sub-types, with better data for resource potential, present and future investment costs, O\&M costs, and anticipated capacity factors. Improving the availability of the data at global and regional scales will be an important ingredient to improving coverage of ocean energy in the scenarios literature [60]

Modeling, in this case, is seen as offering a way to sufficiently constrain the complexity of highly intricate dynamics that must be considered in the course of testing the efficacy of mitigation. Climate modeling, while critical in providing a consistent and informative snapshot of future climate probabilities and the likely success of mitigation strategies, needs further contextualization. Feminist standpoint theory and Longino's feminist contextual empiricism offer an alternative approach to knowledge by incorporating both epistemic and non-epistemic values and concerns into scientific practice.

A much stronger argument with respect to epistemological narrowness can be made about research and analysis conducted on iron fertilization. To be clear, it is the degrees of certainty that need to be unpacked, not certainty as an ontological claim. For example, iron fertilization field trials conducted by university scientists have tended to confine their analysis to technical and scientific factors without addressing the socio-political. A prime example of this can be found in 2009 Indo-German iron fertilization LOHAFEX experiment was conducted in the Southern Atlantic Ocean. In the test, ten tones of FeSO4 was placed over a 300 square kilometer to test ecological changes and fluctuations in the level of carbon.

The publicized justification for the LOHAFEX trial was confined to traditional scientific aims. Their stated objective was to "test the hypothesis that iron fertilization of this ecosystem will promote rapid growth of coastal diatom species which will have a significant effect on the magnitude and composition of vertical flux to the deep sea and underlying sediments" [61]. Testing was done over forty days with conclusions indicating some increase in zooplankton and, most importantly, negligible carbon export, which leaves much to be desired in light of what else a feminist approach might also ask [17]. While it is notable that this and other iron fertilization trials have been similarly disappointing in their results [37]. What is more significant is that no discussion of socio-political, regional or developmental or gender issues are present which have been shown, time and time again, to benefit climate research by drawing attention to relations of power, subordination, context, multiplicity, and equity $[62,63]$.

While it has been argued that in testing such a specific natural phenomenon, namely the ability for iron to promote the growth of zooplankton, gender does not constitute a relevant factor, feminist science scholars counter that this assumption is faulty at its core. That is, FST and FCE both contend that there are no narrow questions or research programs that do not demand due consideration of such factors as gender equity, social justice, ethics and just outcomes. A feminist approach to the testing of zooplankton, consistent with FST and FCE, would entail a front-end assessment of who is involved, with respect to gender, class, race, a potential broadening of research goals, a questioning of ends, and an explicit discussion of justice. Sandra Harding makes a similar argument when she states that even the most seemingly self-contained experiments have consequences and interests outside those systems. According to Harding, "Scientific formulas [and experiments] are like legal judgements: the laws become meaningful only through learning (or deciding) how to apply them and doing so is a process of social interpretation" [22].

It should be made clear, however, this does not mean that feminist approaches to science reject empirical scientific practice. Rather, feminist science studies, inclusive of FST, argue for a kind of science 
that is empirically rigorous while also recognizing that social values and priorities are embedded in science and decision-making. FST and FCE do this in a unique way. Again, my rationale for drawing on Helen Longino's approach to feminist science studies is that it offers an approach to climate science and the environment that is rooted in knowledge critique and critical (re)construction. This method also, when applied to examine climate mitigation strategies such as wind and solar, falls within a broader movement towards climate justice in that it frames science as "situated knowledge, always partial and limited (and never innocent) but also valuable and useable in its partiality" [58,59].

\section{Feminist Standpoint Theory and Feminist Contextual Empiricism}

\subsection{Empirical Adequacy and Human Needs}

The feminist virtues or values that Longino maintains must be incorporated into a more representative, reflexive, and feminist science are those of empirical adequacy, novelty, ontological heterogeneity, complexity or mutuality of interaction and applicability to human needs. In what follows, I provide further justification of the usefulness of FST and FCE in this context and examine two of the five virtues in detail: namely, empirical adequacy and human needs. I first explain what these feminist virtues consist of ideally and in practice, and second, ask whether the science and discourse that surrounds renewable energy and iron fertilization technologies meet these feminist values. As stated, my position is that wind and solar energy technologies are much more in line with the feminist virtues set out by Longino and therefore represent a more equitable approach to climate change that speaks to the concerns of the ethics, social justice, and gender equity.

FCE is particularly well placed to reveal the salient norms and values that constitute both iron fertilization and renewable energy technologies-particularly with respect to issues of fairness and equity. This approach allows for the free expression of marginalized non-dominant values and elevates the belief that knowledge is produced not by discrete individuals but by communities of heterogeneous actors.

The first feminist principle of note, empirical adequacy, refers to "empirical inquiry conducted under feminist strategies" which "has the power to reveal gender and, therefore, it is able to inform feminist projects" and where the "inquiry gains value from that fact" [64]. Empirical adequacy, for Longino, is the one universal standard for research that requires all theories to be accountable to evidence in a manner that is accessible, to and justified by, others in line with publicly agreed upon standards. Empirically adequate theories can be predictive but most importantly, must be compatible with observations. However, because theories are underdetermined (in the Quinean sense that several theories can often explain a particular phenomenon equally well) empirical adequacy rarely functions as a sufficient source of justification in and of itself. This is where the other feminist virtues come in. Feminist empiricism opens space for the view that multiple equally and valid theories can be compatible with available evidence and that, as such, science must be understood as contextual, relative, and shaped by social, political, and cultural values.

Moreover, this model is consistent is with the normative principles of participation and justice in that it requires open and public scrutiny of evidence, methods and assumptions, an uptake of criticism and willingness to alter conclusions based on new evidence, the formation of public standards that address how theories and observations are evaluated and criticism is made relevant, and tempered equality inclusive of equality of intellectual authority [54].

With respect to geoengineering, it is difficult to conclude that the research behind these technologies, and the ways in which they are justified, meet these criteria in a substantive way. For example, in most cases, geoengineering research, inclusive of modeling and, in the case of iron fertilization small-scale testing, has taken place away from public scrutiny with the majority of relevant debate, discussion and diffusion of findings occurring solely among scientists and policy makers. The task of developing a more democratic politics around science and technology is not only reflected in FCE and FST, but has been taken up by scholars of technology, such as Andrew Feenberg 
who argues for the public's participation in technical design in order to ensure the realization of collective goals [65], and feminist theorists like Judy Wajcman who makes the case that all technologies, including environmental ones, contain material, discursive and social elements open to alternative re-articulation [66].

Unfortunately, social science research that has been conducted to better understand public perceptions of geoengineering over the past few years have found that the public "show low levels of awareness and a lack of knowledge" of these technologies as well as a reticence to learn more about them-largely because of their perceived scientific complexity [67]. ${ }^{2}$

Where informed consultation does occur, there is often opposition to the adoption of geoengineering as in the case of the UK Stratospheric Particle Injection for Climate Engineering (SPICE) trial, which was blocked after public discussions. ${ }^{3}$ It has also been suggested that proponents of geoengineering are interested in controlling public debate particularly after finding that the "deficit hypothesis", which asserts that there is a causal link between increased knowledge and support for science, was belied in the case of genetically modified foods.

Conversely, in the case of solar and wind energy, the ways in which studies have been conducted and results communicated do, in the majority of cases, meet the criteria of publicity, criticism, public standards and tempered equality set out by Longino. Studies that incorporate deliberation and justice [71], preferences [72], contextual and psychological factors [73], the role of emotion [74], and sense of place [75], have introduced novel and more inclusive ways to incorporate the public into the implementation and assessment of energy alternatives. Additionally, the media has been rather adept in mainstreaming information about renewable energy into the dominant discourse. However, the quality and ideological framing of media coverage differs markedly between and within countries as well as with respect to the varied political position of individual publications [76].

Additionally, a large number of government commissioned studies have been done to gauge public support for wind and solar energy initiatives as well as ones that aim to involve the public in the planning and execution of such projects $[77,78]$. (Generally, both quantitative and qualitative studies show there is broad support for renewable energy [79-81]. However, it is important to note that acceptance and rejection of these technologies is quite variable and dependent on a variety of factors, including gender, age, income, education etc.

As distinct approaches to climate mitigation, it is also important to highlight how the differences between iron fertilization and renewable energy represent more than just disagreements over policy. Rather, they exemplify divergent structural, ideological, and normative approaches to growth and development. On the one hand, geoengineering technologies are consistent, at least in kind, with other production-oriented technologies that value control and prescription, while often ignoring context and externalities, whereas growth-oriented technologies, such as those typified by wind and solar energy, because of their decentralized structure, tend to be more responsive context and external effects [82-84]. There is a rich body of literature that details the precise ways in which the structural characteristics of technologies shape socio-political relations, which, while I am unable to discuss further here, can also be used to assess the technologies at hand [85-87].

\subsection{Applicability to Human Needs}

The second feminist virtue, applicability to current human needs, argues in favor of those theories, research programs and frameworks that are oriented towards easing suffering, acting against injustice, and improving the human condition. The use of science in reducing "hunger ... assisting the infirm,

\footnotetext{
It should be noted that research in this area is increasing. Some studies have reached conflicting conclusions [68,69]. This project was also in violation of the Oxford Principles (http://www.geoengineering.ox.ac.uk/oxford-principles/ principles/). There is also conflicting evidence in this area - some of which suggests that the picture is much more complex and that while the public might be reticent to support field trials, basic research is not opposed [70].
} 
protecting or reversing the destruction of the environment" is privileged, as is support "for research that can be directed towards meeting the human and social needs traditionally ministered by women" [88].

With respect to iron fertilization, the majority of work done in favor of its adoption asserts that it will meet human needs. Generally, arguments in support of geoengineering fall into three categories as outlined in Working Group III's contribution to the 5th Assessment Report to the IPCC [89]. First, is the lesser evil argument $[54,90,91]$. This particular claim asserts that failure to address climate change is likely and that, given the option of suffering through its potentially catastrophic side effects versus engaging in geoengineering, preparing for its future use is necessary.

Second is the tipping point argument which specifically contends that the 2 degrees Celsius warming limit set by the IPCC, and generally agreed upon by the majority of climate scientists, cannot and will not be met due to self-interest, policy inertia, political gridlock, and a general lack of will. As such, geoengineering is presented as offering humanity a technologically attractive "plan B" through which to address climate change [54,92]. Finally, there is the argument of cost-effectiveness. Put simply, it is claimed that geoengineering offers the most cost-effective strategy with a relatively high chance of success in mitigating climate change. Iron fertilization is seen as cost effective specifically since the cost of fertilizing material, in relation to the quantity required, is insubstantial [93].

However, scholars such as Clive Hamilton have pointed out that despite being presented as a technology that could address climate change and save humanity from the effects of human induced global warming, geoengineering actually encourages and reproduces traditional power structures in society by alleviating pressure on governments and corporations to move away from unsustainable fossil fuel production and consumption. He states that,

Like a patient who will accept the doctor's diagnosis only if the illness is treatable, a solution to global warming that does not destabilize a person's worldview - but in fact validates it-makes recognizing the problem palatable .... As the identity of conservative white males tends to be more strongly bound to the prevailing social structure, geoengineering is the kind of solution to climate change that is less threatening to their values and sense of self .... they are consistent with the ideas of control over the environment and the personal liberties associated with free market capitalism. Just as the need to defend a cultural worldview makes conservative white males prone to repudiate climate science, so that worldview will make them prone to support geoengineering solutions [27]

The litany of potential side effects of iron fertilization further removes this approach from meeting the human needs of dignity, security, autonomy, and recognition. These include ecological effects such as the possible overproduction of algae blooms and the creation of anoxic or low oxygen conditions-both of which could negatively impact marine food chains and, because of anoxia, further stimulate the emission of methane and nitrous oxide [17].

Other problems that might affect the fulfillment of human needs include concerns that iron fertilization climate engineering might result in the suppression of Asian monsoons leading to food insecurity for the most vulnerable [94]. The possibility of catastrophic human error, and questions over whether geoengineering meets the criteria of the precautionary principle with respect to agreement over the threshold trigger and termination (who decides?) and, most importantly, the magnitude and possibility of unanticipated environmental and social harm [95]. Clear governance mechanisms have also not been constructed and, due to present political conditions, are unlikely to be. Also of concern with respect to human needs are consequences associated with the moral hazard argument which warns that geoengineering may become a means through which to put off much needed changes to resource intensive production processes, consumption levels, and current modalities of energy use.

Finally, in a critical discussion of race and gender, Hamilton points out the deep racial and gender inequalities that characterize engagement in geoengineering research (which is overwhelmingly male and white) while also drawing attention to the fact that some of its biggest proponents are reformed climate change deniers who now see a means by which to tacitly acknowledge that climate change 
is happening while maintaining the current economic system. Yet, it is also the case this does not entirely preclude the possibility that geoengineering could be used to reduce suffering or the prospect that wind and solar energy technologies could also be used to keep power structures in place. Rather, the point is that geoengineering has a long way to go before meeting the human needs test.

The majority of work that argues for the adoption of wind and solar energy comes out of the governmental and NGO sectors, which generally do meet the basic requirements of the "addressing human needs" virtue. A clear example of this can be found in a 2014 report written for the International Development Bank's (IDB) Gender and Diversity Division titled “Gender and Renewable Energy: Wind, Solar, Geothermal and Hydroelectric Energy". In it, a focused gendered perspective is incorporated into the study of how medium- and large-scale renewable energy projects can be better constructed and operationalized to meet the needs of women. The report pays specific attention to lack of women's participation in consultation processes by focusing on women's unique daily needs as well as such barriers as social norms and lack of education. It points out that issues of scheduling related to meal preparation and other daily tasks must be considered as well as channels of communication wherein "a poster in a school or market or an invitation sent to women's associations could be the most appropriate method for announcing the project to women, while a poster posted at a town hall could reach more men" [96].

Concrete ways to promote female employment at wind and solar plants, as well as through the supply chain, is also discussed in the report with particular attention paid to training and education initiatives similar to the one used by Mexico's National Institutes for Women. Employment in renewable energy and green jobs, as Marjorie Griffin Cohen argues, is largely taken up by men since the training tends to build on top of the building, trades. and transportation sectors which are a priori dominated by men [97]. Additionally, the need to provide women with joint title and direct compensation for land resettlement is highlighted as is a thorough discussion of the material benefits of renewable energy on women as a result of stable access to clean energy including, "the reduction of time dedicated to household tasks, income generation, as well as health and safety improvements" [96].

Overall, it is clear that about geoengineering needs to incorporate a better account of human needs and its interaction with other vectors of identity and social positionality. Thus far, there has been little written on the subject with respect to iron fertilization in particular. The one exception is a 2014 article written for Hypatia in which the authors explore the relevance of gender to geoengineering with respect to the demographics of those involved (largely male); the dominating vision of control over nature it embodies, its masculinist design; and the likely unequal distribution of risk and benefits it entails [98].

\section{Conclusions}

My objective in this article has been to develop a feminist approach to evaluating two distinct paths towards dealing with climate change, namely, renewable energy and ocean fertilization geoengineering. By providing a detailed analysis of the ways in which gender has been inserted into the study of climate change, and the problems with each perspective, my hope is that it becomes possible to move forward in a manner that pays more attention to the values of equity and justice in the development of future projects. ${ }^{4}$ As well, in unpacking the specific values of feminist science put forth by FCE and FST, I have attempted to open a new space through which to insert gender into discussions around climate change mitigation in ways that pursue larger goals of fairness and inclusiveness which also form the core of feminist science. As illustrated, incorporating feminist contextual empiricism into scientific modeling in general, and geoengineering in particular, results in an ability to lay bare and critically

4 A laudable first step has also been made by endeavours like the "Gendered Innovations" project, a joint UK/US project which aims to embed a gendered analysis into multiple STEM fields including the environment. Their climate change project, for example, draws embeds equality into contemporary research as well as advocating for research protocols that are flexible, non linear, and adaptable (http:/ / genderedinnovations.stanford.edu). 
examine the implications of gendered values, methods, and truth claims in ways that leave space for alternative approaches that better meet the feminist objectives of equality, justice, heterogeneity, and openness. Employing FST in conjunction with FCE allows for a more robust centering of gendered experiences as epistemologically productive in and of themselves.

As such, it is important that future research into geoengineering highlight the role values play in its construction while also aspiring to be more reflexive, interactive, oppositional, inclusive, and local in its approach. My conclusion is that ocean fertilization geoengineering in particular, has not met and does not meet the objectives of gender awareness and justice articulated by FST and FCE. Its tendency to rely on values of empiricism and objectivity with low levels of public participation leaves much to be desired. Research into renewable energy initiatives, on the other hand, hold out much more promise of attaining feminist virtues of heterogeneity, richness, and publicity. While more work needs to be done in this area; my hope is that this research adds to the debate.

Funding: This research received no external funding.

Conflicts of Interest: The author declares no conflicts of interest.

\section{References}

1. IPCC. Global warming of $1.5^{\circ} \mathrm{C}$. 2018. Available online: http://www.ipcc.ch/report/sr15/ (accessed on 23 October 2018).

2. Martin, P.; Loeff, M.R.; Cassar, N.; Vandromme, P.; d'Ovidio, F.; Stemmann, L.; Rengarajan, R.; Soares, M.; González, H.E.; Ebersbach, F. Iron Fertilization Enhanced Net Community Production But not Downward Particle Flux during the Southern Ocean Iron Fertilization Experiment LOHAFEX. Glob. Biogeochem. Cycles 2013, 27, 871-881. [CrossRef]

3. Buesseler, K.O. Biogeochemistry: The Great Iron Dump. Nature 2012, 487, 305-306. [CrossRef] [PubMed]

4. Roland, A.M. To Act or not to Act: A Proposal for Domestic Geoengineering Governance. Available online: https:/ /issuu.com/jofspg/docs/domestic_geoengineering_governance/21 (accessed on 4 August 2018).

5. Tollefson, J. Iron-Dumping Ocean Experiment Sparks Controversy. Nature. 2017. Available online: https: / /www.nature.com/articles/n-12306030 (accessed on 10 August 2017).

6. Anderson, E. Value in Ethics and Economics; Harvard University Press: Cambridge, MA, USA, 1993.

7. Anderson, E. Feminist Epistemology: An Interpretation and Defense. Hypatia 1995, 10, 50-84. [CrossRef]

8. Coady, C.A.J. Testimony: A Philosophical Study; Clarendon Press: Oxford, UK, 1992.

9. Nelson, L. Who Knows? From Quine to a Feminist Empiricism; Temple University Press: Philadelphia, PA, USA, 1990.

10. Tuana, N. The Radical Future of Feminist Empiricism. Hypatia 1992, 7, 100-114. [CrossRef]

11. Longino, H.E. Cognitive and Non-Cognitive Values in Science: Rethinking the Dichotomy. In Feminism, Science, and the Philosophy of Science; Nelson, L.H., Nelson, J., Eds.; Kluwer Academic Publishers: Dordrecht, The Netherlands, 1996.

12. Longino, H.E. Can There Be a Feminist Science? Hypatia 1987, 2, 51-64. [CrossRef]

13. Assiter, A. Enlightened Women: Modernist Feminism in a Postmodern Age; Routledge: New York, NY, USA, 2010.

14. Clough, P.T. Feminist Thought; Blackwell Publishers: Cambridge, MA, USA, 1994.

15. Woolgar, S. A New Theory of Innovation? Prometheus 1998, 16, 441-452. [CrossRef]

16. Collins, H. Changing Order: Replication and Induction in Scientific Practice; University of Chicago Press: Chicago, IL, USA, 2003.

17. Strong, A.L.; CuLLeN, J.J.; ChiShOLm, S.W. Ocean Fertilization: Science, Policy and Commerce. Oceanography 2009, 22, 236-261. [CrossRef]

18. Blisset, M. Politics in Science; Little, Brown and Co.: Boston, MA, USA, 1972.

19. Halliday, M.A.K. Language as Social Semiotic; Edward Arnold: London, UK, 1978.

20. Potter, J. Discourse Analysis. In Handbook of Data Analysis; Hardy, M., Bryman, A., Eds.; Sage: London, UK, 2004; pp. 607-624.

21. Keller, E.F. Reflections on Gender and Science; Yale University Press: New Haven, NY, USA, 1985.

22. Harding, S. The Science Question in Feminism; Cornell University: Ithica, NY, USA, 1986.

23. Tuana, N.; Cuomo, C.J. Climate Change-Editors' Introduction. Hypatia 2014, 29, 533-540. [CrossRef] 
24. Alston, M. Gender Mainstreaming and Climate Change. Women's Stud. Int. Forum 2014, 47, $287-294$. [CrossRef]

25. Harding, S. Whose Science? Whose Knowledge? Thinking from Women's Lives; Cornell University Press: New York, NY, USA, 2016.

26. Coony, J.; Deeb, A.; Ebinger, J.; Leino, I.; Lier, O.; Lopes, V.; Madrigal, M.; Vergara, W. Climate Impacts on Energy Systems: Key Issues for Energy Sector Adaptation; ESMAP: Washington, DC, USA, 2010.

27. Hamilton, C. Earthmasters: The Dawn of the Age of Climate Engineering; Yale University: New Haven, CT, USA, 2013.

28. Lewis, J.I.; Wiser, R.H. Fostering a Renewable Energy Technology Industry: An International Comparison of Wind Industry Policy Support Mechanisms. Energy Policy 2007, 35, 1844-1857. [CrossRef]

29. Milligan, M.; Frew, B.; Kirby, B.; Schuerger, M.; Clark, K.; Lew, D.; Denholm, P.; Zavadil, B.; O’Malley, M.; Tsuchida, B. Alternatives no more: Wind and solar power are mainstays of a clean, reliable, affordable grid. IEEE Power Energy Mag. 2015, 13, 78-87. [CrossRef]

30. Soder, L.; Abildgaard, H.; Estanqueiro, A.; Hamon, C.; Holttinen, H.; Lannoye, E.; Gomez-Lazaro, E.; O'Malley, M.; Zimmermann, U. Experience and challenges with short-term balancing in European systems with large share of wind power. IEEE Trans. Sustain. Energy 2012, 3, 853-861. [CrossRef]

31. International Energy Agency. Executive Summary. International Energy Agency. 2014. Available online: https:/ / www.iea.org/Textbase/npsum/EEMR2014SUM.pdf (accessed on 30 August 2018).

32. Bertram, C. Ocean Iron Fertilization in the Context of the Kyoto Protocol and the Post-Kyoto Process. Energy Policy 2010, 38, 1130-1139. [CrossRef]

33. Aramaki, T.; Nojiri, Y.; Imai, K. Behavior of Particulate Materials During Iron Fertilization Experiments in the Western Subarctic Pacific (SEEDS and SEEDS II). Deep-Sea Res. Part II Top. Stud. Oceanogr. 2009, 56, 2875-2888. [CrossRef]

34. Güssow, K.; Oschlies, A.; Andreas, P.A.; Rehdanz, K.; Rickels, W. Ocean Iron Fertilization: Why Further Research Is Needed. Mar. Policy 2010, 34, 911-918. [CrossRef]

35. Batten, S.; Grower, J.F.R. Did the Iron Fertilization near Haida Gwaii in 2012 Affect the Pelagic Lower Trophic Level Ecosystem? Plankton Res. 2014, 36, 925-932. [CrossRef]

36. Buesseler, K.O.; John, A.E.; Pike, S.M.; Charette, M.A. The Effects of Iron Fertilization on Carbon Sequestration in the Southern Ocean. Science 2004, 304, 414-417. [CrossRef] [PubMed]

37. Buesseler, O.K.; Boyd, P.W. Will Ocean Fertilization Work? Science 2003, 300, 67-68. [CrossRef] [PubMed]

38. Abate, S.R.; Greenlee, A.B. Sowing Seeds Uncertain: Ocean Iron Fertilization, Climate Change, and the International Environmental Law Framework. Pace Environ. Law Rev. 2009, 27, 555.

39. European Commission. Guidance to Facilitate the Implementation of Targets to Promote Gender Equality in Research and Innovation; European Commission: Brussels, Belgium, 2018. Available online: http://ec.europa.eu/ research/swafs/pdf/pub_gender_equality/KI-07-17-199-EN-N.pdf (accessed on 23 October 2018).

40. Climate Engineering News. Iron fertilization in Canada/Haida Gwaii (7th Update). Climate Engineering News. 2013. Available online: http:/ / www.climate-engineering.eu/single/press-review-iron-fertilizationin-canada.html (accessed on 1 September 2018).

41. European Commission. Horizon 2020: Closing Gender Gaps in Research and Innovation; European Commission: Brussels, Belgium, 2018. Available online: http:/ / ec.europa.eu/research/swafs/pdf/pub_gender_equality / closing_gender_gaps_infographics.pdf (accessed on 23 October 2018).

42. Hannan, C. Gender Mainstreaming Climate Change. 2009. Available online: https://doi.org/10.1016/j.wsif. 2013.01.016 (accessed on 4 August 2015).

43. Plehwe, D.; Walpen, B.J.; Neunhöffer, G. (Eds.) Neoliberal hegemony: A Global Critique; Routledge: London, UK, 2007.

44. Bacchi, C.; Eveline, J. Mainstreaming and Neoliberalism: A Contested Relationship. Policy Soc. 2003, 22, 98-118. [CrossRef]

45. Ajibade, I.; McBean, G.; Bezner-Kerr, R. Urban Flooding in Lagos, Nigeria: Patterns of Vulnerability and Resilience Among Women. Glob. Environ. Chang. 2013, 23, 1-12. [CrossRef]

46. Ariyabandu, M.M. Disasters and Social Vulnerabilities in Asia and the Pacific. In The United Nation Office for Disaster Risk Reduction; UNISDR: Geneva, Switzerland, 2012.

47. Kabeer, N. Mainstreaming Gender in Social Protection for the Informal Economy. In New Gender Mainstreaming Series on Development Issues; Commonwealth Secretariat: London, UK, 2008. 
48. Mitchell, T.; Tanner, T.M.; Lussier, K. We Know What We Need: South Asian Women Speak Out on Climate Change Adaptation. In Action-Aid International and Institute of Development Studies; University of Sussex: Brighton, UK, 2007. Available online: http://www.eldis.org/go/display\&type=Document\&id=35433 (accessed on 14 July 2015).

49. Karlsson, G.; Owren, C.; Rojas, A.; Harris, R. Gender, Energy Technology and Climate Change; WEDO and Energia: New York, NY, USA, 2010.

50. Angula, M. Gender and Climate Change: Namibia Case Study; Heinrich Böll Stiftung Southern Africa: Cape Town, South Africa, 2010.

51. MacGregor, S. No sustainability without justice: A feminist critique of environmental citizenship. In Environmental Citizenship; MIT Press: Cambridge, MA, USA, 2006; pp. 101-126.

52. MacGregor, S. ‘Gender and climate change': From impacts to discourses. J. Indian Ocean Reg. 2010, 6, $223-238$. [CrossRef]

53. Intemann, K. 25 Years of Feminist Empiricism and Standpoint Theory: Where Are We Now? Hypatia 2010, 25, 778-796. [CrossRef]

54. Crasnow, S. Feminist Philosophy of Science: Values and Objectivity. Philos. Compass 2013, 8, $413-423$. [CrossRef]

55. Hekman, S. Truth and Method: Feminist Standpoint Theory Revisited. Signs 1997, 22, 341-365. [CrossRef]

56. Baert, P.; Rubio, F.D. Philosophy of the Social Sciences. In The New Blackwell Companion to Social Theory; Turner, B.S., Ed.; Blackwell: Oxford, UK, 2009; pp. 60-80.

57. Nelson, L.; Nelson, J. On Feminist Philosophy; Wadsworth Publishing: Belmont, CA, USA, 2008.

58. Israel, L.A.; Sachs, C. A Climate for Feminist Intervention: Feminist Science Studies and Climate Change. In Research, Action, Action and Policy: Addressing the Gendered Impacts of Climate Change; Alston, M., Whittenbury, K., Eds.; Springer: New York, NY, USA, 2013; pp. 33-51.

59. Haraway, D. Situated Knowledges: The Science Question in Feminism and the Privilege of Partial Perspective. Fem. Stud. 1988, 14, 575-599. [CrossRef]

60. IPCC. Renewable Energy Sources and Climate Change Mitigation: Summary for Policymakers and Technical Summary. In Technical Support Working Group III; Potsdam Institute for Climate Impact Research Impact: Potsdam, Germany, 2014.

61. Smetacek, V.; Naqvi, S.W.A. The Next Generation of Iron Fertilization Experiments in the Southern Ocean. Philos. Trans. R. Soc. Lond. A Math. Phys. Eng. Sci. 2008, 366, 3947-3967. [CrossRef] [PubMed]

62. Carpenter, S.R.; Mooney, H.A.; Agard, J.; Capistrano, D.; DeFries, R.S.; Díaz, S.; Dietz, T.; Duraiappah, A.K.; Oteng-Yeboah, A.; Pereira, H.M. Science for managing ecosystem services: Beyond the Millennium Ecosystem Assessment. Proc. Natl. Acad. Sci. USA 2009, 106, 1305-1312. [CrossRef] [PubMed]

63. Rotmans, J.; van Asselt, M. (Eds.) Integrated assessment modelling. In Climate Change: An Integrated Perspective; Springer: Dordrecht, The Netherlands, 1999; pp. 239-275.

64. Lacey, H. Is Science Value Free? Values and Scientific Understanding; Routledge: London, UK, 1999.

65. Feenberg, A. Transforming Technology: A Critical Theory Revisited; Oxford University Press: Oxford, UK, 2002.

66. Wajcman, J. From Women and Technology to Gendered Technoscience. Inf. Commun. Soc. 2007, 10, $287-298$. [CrossRef]

67. Scheer, D.; Renn, O. Public Perception of Geoengineering and its Consequences of Public Debate. Clim. Chang. 2012, 125, 305-318. [CrossRef]

68. Corner, A.; Parkhill, K.; Pidgeon, N.; Vaughan, N.E. Messing with Nature? Exploring Public Perceptions of Geoengineering in the UK. Glob. Environ. Chang. 2013, 23, 938-947. [CrossRef]

69. Mercer, M.A.; Keith, D.W.; Sharp, J.D. Public Understanding of Solar Radiation Management. Environ. Res. Lett. 2011, 6, 044006. [CrossRef]

70. Merk, C.; Pönitzsch, G.; Kniebes, C.; Rehdanz, K.; Schmidt, U. Exploring Public Perceptions of Solar Radiation Management; No. Working Paper; Kiel Institute for the World Economy: Kiel, Germany, 2014.

71. Phadke, R. Public Deliberation and the Geographies of Wind Justice. Sci. Cult. 2013, 22, 247-255. [CrossRef]

72. Engels, A.; Huether, O.; Schaefer, M.; Held, H. Public Climate-Change Skepticism, Energy Preferences and Political Participation. Glob. Environ. Chang. 2013, 23, 1018-1027. [CrossRef]

73. Perlaviciute, G.; Steg, L. Contextual and Psychological Factors Shaping Evaluations and Acceptability of Energy Alternatives: Integrated Review and Research Agenda. Renew. Sustain. Energy Rev. 2014, 35, 361-381. [CrossRef] 
74. Smith, N.; Leiserowitz, A. The Role of Emotion in Global Warming Policy Support and Opposition. Risk Anal. 2014, 34, 937-948. [CrossRef] [PubMed]

75. Carlisle, E.J.; Kane, S.L.; Solan, D.; Joe, J.C. Support for Solar Energy: Examining Sense of Place and Utility-Scale Development in California. Energy Res. Soc. Sci. 2014, 3, 124-130. [CrossRef]

76. Boykoff, T.M.; Roberts, J.T. Media Coverage of Climate Change: Current Trends, Strengths, Weaknesses. In UN Human Development Report; Human Development Report Office: New York, NY, USA, 2007.

77. Devine-Wright, P. A Cross-National, Comparative Analysis of Public Understanding of, and Attitudes Towards Nuclear, Renewable and Fossil-Fuel Energy Sources. In Proceedings of the 3rd Conference of the EPUK (Environmental Psychology in the UK) Network: Crossing Boundaries-The Value of Interdisciplinary Research; Robert Gordon University: Aberdeen, UK, 2003; pp. 160-173.

78. Braunholtz, S. Public Attitudes to Windfarms: A Survey of Local Residents in Scotland. Scottish Executive Social Research/MORI Scotland. 2003. Available online: http:/ /www.scotland.gov.uk/library5/ environment/ pawslr.pdf (accessed on 4 August 2015).

79. Jobert, A.; Laborgne, P.; Mimler, S. Local Acceptance of Wind Energy: Factors of Success Identified in French and German Case Studies. Energy Policy 2007, 35, 2751-2760. [CrossRef]

80. Hall, N.; Ashworth, P.; Devine-Wright, P. Societal Acceptance of Wind Farms: Analysis of Four Common Themes Across Australian Case Studies. Energy Policy 2013, 58, 200-208. [CrossRef]

81. Baris, K.; Kucukali, S. Availability of Renewable Energy Sources in Turkey: Current Situation, Potential, Government Policies and the EU Perspective. Energy Policy 2012, 42, 377-391. [CrossRef]

82. Leach, M.; Scoones, I.; Stirling, A. Dynamic Sustainabilities: Technology, Environment, Social Tustice; Earthscan: London, UK, 2010.

83. Franklin, U. The Real World of Technology; House of Anansi: Toronto, ON, Canada, 1999.

84. Horkheimer, M.; Adorno, T.W.; Noeri, G. Dialectic of Enlightenment; Stanford University Press: California, CA, USA, 2002.

85. Winner, L. Do Artifacts have Politics. In Readings in the Philosophy of Technology; Rowman \& Littlefield Publishers: Lanham, MD, USA, 2004; pp. 251-263.

86. MacKenzie, D.; Wajcman, J. The Social Shaping of Technology; Open University Press: London, UK, 1999.

87. Woolgar, S. The Turn to Technology in Social Studies of Science. Sci. Technol. Hum. Values 1991, 16, 20-50. [CrossRef]

88. Longino, H.E. Gender, Politics, and the Theoretical Virtues. Synthese 1995, 104, 383-397. [CrossRef]

89. Working Group III. Climate Change 2014: Mitigation of Climate Change. In Fifth Assessment Report of the IPCC; Cambridge University: Cambridge, UK, 2015.

90. Svoboda, T. The Ethics of Geoengineering: Moral Considerability and the Convergence Hypothesis. J. Appl. Philos. 2012, 29, 243-256. [CrossRef]

91. Betz, G. The Case for Climate Engineering Research: An Analysis of the Arm the Future Argument. Clim. Chang. 2012, 111, 473-485. [CrossRef]

92. Sandler, R.L. Ethics and Emerging Technologies; Palgrave MacMillan: New York, NY, USA, 2013.

93. Lampitt, R.S.; Achterberg, E.P.; Anderson, T.R.; Hughes, J.A.; Iglesias-Rodriguez, M.D.; Kelly-Gerreyn, B.A.; Lucas, M.; Popova, E.E.; Sanders, R.; Shepherd, J.G.; et al. Ocean Fertilization: A Potential Means of Geoengineering. Philos. Trans. R. Soc. 2008, 366, 3919-3945. [CrossRef] [PubMed]

94. The Royal Society. Geoengineering the Climate: Science, Governance and Uncertainty; The Royal Society: London, UK, 2009. Available online: http:/ / royalsociety.org/geoengineering-the-climate/ (accessed on 15 October 2014).

95. Robock, A. 20 Reasons Why Geoengineering May Be a Bad Idea. Bull. Atom. Sci. 2008, 64, 14-15. [CrossRef]

96. International Development Bank (IDB). Gender and Renewable Energy: Wind, Solar, Geothermal and Hydroelectric Energy. Gender and Diversity Division, Social Sector, November 2014. Available online: http:/ /idbdocs.iadb.org/wsdocs/getdocument.aspx?docnum=39647922 (accessed on 30 September 2015). 
97. Cohen, M.G. Gendered Emissions: Counting Greenhouse Gas Emissions by Gender and Why It Matters. Available online: http:/ / www.alternateroutes.ca/index.php/ar/article/viewFile/20595/16990 (accessed on accessed on 4 August 2015).

98. Buck, H.J.; Andrea, R. Gammon and Christopher Preston, Gender and Geoengineering. Hypatia 2014, 29, 651-669. [CrossRef] 